\title{
Wind stress limitation of benthic secondary production in shallow, soft-sediment communities
}

\author{
Craig W. Emerson \\ Department of Oceanography, Dalhousie University, Halifax, Nova Scotia, Canada B3H 4J1
}

\begin{abstract}
Local wind fields can determine the magnitude of coastal benthic secondary production (BSP) via regulation of metabolically-important environmental factors (e.g. water temperature, mixing depth, food supply, sediment transport) by wind-forced hydrodynamics. This hypothesis was tested using 201 published estimates of BSP and local wind field data. Wind stress was significantly correlated with Total-, Macro-, and Meio-benthic secondary production in a negative manner $\left(R^{2}=0.32,0.12,0.52\right.$ respectively: $p<0.001$ ). Multiple regression analysis demonstrated that wind stress, tidal height, shelter indices and water temperature explained $\sim 90 \%$ of the variance in Total-BSP. Neither benthic nor pelagic primary production contributed to a significant reduction in BSP variance. Data support the concept of a physical regulation of coastal benthic energy flow and suggest that the effect of wind stress on BSP is mediated largely by sediment transport.
\end{abstract}

\section{INTRODUCTION}

Tight vertical coupling has been incorporated consistently into models describing pelagic-benthic energetics because the sedimentation of phytoplankton, fecal pellets and detritus represents a major source of particulate organic matter (POM) for the benthos (Rowe 1971, Hinga et al. 1979, Hopkinson 1985). An empirical model developed by Hargrave (1973) successfully utilized annual primary production $\left(\mathrm{C}_{\mathrm{s}}\right)$ and depth of mixing $\left(Z_{m}\right)$ to predict the magnitude of benthic respiration $\left(\mathrm{C}_{0}\right)$ in predominantly deep-water communities: $\mathrm{C}_{\mathrm{o}}=55\left(\mathrm{C}_{\mathrm{s}} / \mathrm{Z}_{\mathrm{m}}\right)^{0.39}$. It was recognized, however, that this model is unlikely to apply in near-shore areas with high advective flow, where allochthonous POM could contribute substantially to the carbon budget.

The vertical flux of POM is frequently insufficient to account for the observed benthic metabolism in numerous coastal communities, and lateral advective input is invariably incorporated to balance the energy budget (Graf et al. 1984, Hargrave \& Phillips 1986, Gordon et al. 1987). Conversely, an apparent excess of POM sedimentation has been recognized at a site in the lower Bay of Fundy (Emerson et al. 1986). It was suggested that this excess was laterally transported to an extensive horse mussel bed in an adjacent area of the Bay. Other studies have shown that horizontal POM flux resulting from riverine, wind and tidal forcing may equal or exceed autochthonous benthic and pelagic primary production (Wolff 1977, Hartwig 1978, Lesht \& Hawley 1987). It is apparent that hydrodynamicallyactive ecosystems must be modelled in a framework which combines these horizontal fluxes with the traditional concept of a vertical energy link.

In the Bay of Fundy (E Canada), tidal currents may be a major determinant of benthic distribution and production by controlling settlement, growth and feeding of benthic animals (Wildish \& Peer 1983). In addition, the influence of wind-forced hydrodynamics on the plankton and the sediment has been widely recognized even in strongly tidal environments (Levasseur et al. 1983, Soniat et al. 1984, Pejrup 1986). Although the effects of wind forcing are most apparent in shallow depths, storms can generate significant sediment disturbance at depths greater than $100 \mathrm{~m}$ (Drake \& Cacchione 1985). It is likely therefore, that wind-field analysis will improve models of benthic energetics because the effects of many physical processes on biological production can be integrated in the local wind stress.

The development of a surface mixed layer by wind forcing may limit the amount of photosyntheticallyderived POM available to the benthos by determining the availability of nutrients and light necessary for primary production (Pingree 1980, Lewis et al. 1984, Demers et al. 1987), and by regulating the residence 
time (and therefore the utilization) of POM in the water column (Hargrave 1973). Oxygenation of anoxic bottom water (Soniat et al. 1984), and an increase in the depth of oxygen penetration into the sediment by wind-forced wave action (Rutgers van der Loeff 1981), can potentially increase aerobic benthic metabolism.

Wind may also influence the benthos by increasing bottom currents beyond the critical erosion velocity of the sediment. Subsequent sediment transport (i.e. bedload and suspended load) may result in an energetic subsidy, whereby previously buried POM is made available to a food-limited community. In addition, sediment disturbance has been shown to enhance metabolic activity in both micro- and macrofauna (Findlay et al. 1985, Jumars \& Self 1986, Miller \& Jumars 1986). Alternatively, sediment transport may exert an energetic stress via resource depletion, direct inhibition of suspension feeding and burial of nonmotile organisms and removal of epi- and infauna during storms. It follows that a balance between stress and subsidy from sediment movement will be reflected in the production and community structure of the benthos.

The utility of wind analysis in investigations of benthic energy flow was assessed by (1) determining if wind and coastal benthic production are correlated using published estimates of benthic secondary production and wind speed, and (2) by including wind in a data base of biologically-important environmental variables which could be used to develop a general empirical model of benthic production. In addition to providing estimates of benthic production on a wide spatial scale, it is hoped that this model will stimulate and facilitate further research by identifying those variables most likely responsible for variations in benthic metabolism.

\section{MATERIALS AND METHODS}

Biotic variables. Estimates of benthic secondary production (BSP) and benthic/pelagic primary production $(\mathrm{BPP} / \mathrm{PPP})$ were obtained from the literature. BSP was partitioned into total benthic secondary production (Total-BSP), total macrobenthic secondary production (Macro-BSP) and total meiobenthic secondary production (Meio-BSP), where possible. The lack of direct measurements of microbenthic secondary production prevented the addition of this dependent variable to the production models. It was possible, however, to determine the relative proportion of Total-BSP accounted for by the microbenthos by calculating the difference between Total-BSP and [Meio-BSP + Macro-BSP] at some study sites.

Species-specific production estimates were excluded unless their contribution to total production was measured. Every effort was made to obtain BSP, BPP and PPP estimates from the same location and year, however pairing of PPP with BSP on tidal flats was frequently restricted to the use of PPP estimates at adjacent subtidal sites.

Selection of production data was not restricted to those studies which employed identical methods of estimation; i.e. it was assumed a priori that methodological variation in BSP measurement was less than variation due to spatial wind effects. Published Macro-BSP estimates were calculated by using either the summation of growth increments or by using production: biomass ratios (Crisp 1971). Determination of annual production of the total-and meio-fauna $\left(P_{a}, k c a l\right.$ $\mathrm{m}^{-2} \mathrm{yr}^{-1}$ ) from respiration estimates $\left(\mathrm{R}_{\mathrm{a}}\right)$ followed Schwinghamer et al. (1986):

$$
\log _{10} R_{a}=0.367+0.993 \log _{10} P_{a}
$$

Chemical oxygen demand of the sediment was subtracted from estimates of total sediment oxygen uptake to calculate benthic respiration. BPP and PPP had been determined using either the ${ }^{14} \mathrm{C}$ or $\mathrm{O}_{2}$ exchange techniques. All units of production were standardized $\left(\mathrm{kJ} \mathrm{m}^{-2}\right.$ $\mathrm{yr}^{-1}$ ) using the following conversions (Holme \& McIntyre 1971): $1 \mathrm{cal}=4.185 \mathrm{~J} ; 1 \mathrm{~g}$ ash-free dry weight $=4.23 \mathrm{kcal}_{i} 1 \mathrm{~g}$ carbon $=12 \mathrm{kcal}_{i} 1 \mathrm{ml} \mathrm{O} 2\left(\mathrm{mg} \mathrm{O}_{2}\right)$ respired $=4.83 \mathrm{cal}(3.38 \mathrm{cal})$.

Physical variables. Wind velocities $(V)$ were obtained from climatological records (e.g. British Meteorology Office 1952, U.S. Navy Marine Climatic Atlas 1974, Ruffner 1978). Surface wind stress $\left(\hat{\tau}_{0}\right)$ was estimated by:

$$
\hat{\tau}_{o}=\rho_{a} \quad C_{d} \cdot V^{2}
$$

where $\rho_{\mathrm{a}}=$ air density $\left(1.3 \mathrm{~kg} \mathrm{~m}^{-3}\right) ; C_{d}=\mathrm{a} V$-dependent drag coefficient $\left(1.14 \times 10^{-3}\right.$ for $V \leq 10 \mathrm{~m} \mathrm{~s}^{-1}$ and $[0.49+0.065(V)] \times 10^{-3}$ when $V$ is greater than $10 \mathrm{~m}$ $\mathrm{s}^{-1}$; Thompson et al. 1983).

Two shelter indices indicated the relative protection of a study site from the wind: (1) effective fetch (EF) was defined as the maximum distance along the sea surface on which the annual mean wind exerts stress, and (2) headwind index (HW) was the difference between the annual mean wind direction and the direction of maximum exposure of the study site $\left(0^{\circ}=\right.$ min. shelter, $180^{\circ}=\max$. shelter). Tidal height was included as a rudimentary index of tidal current and degree of air exposure at intertidal sites.

Sediment grain size is important to many processes that affect benthic community structure and function, however such data were seldom included in published studies of benthic production. Accordingly, a qualitative sediment size index was assigned to each study site: 0 to $5=4.0$ to -1.0 in the Phi grain size scale. 
Water temperature and salinity were available from the literature. The data set and sources of all variables are available from the author

Statistical analyses. The data distribution of each variable was normalized where necessary by log, inverse or square-root transformations. Analysis of residuals indicated which transformation best removed the dependence of variance on the given regressor variable, rather than that which maximized $R^{2}$. Initial identification of the environmental variables significantly related to the production variables was accomplished by constructing a Pearson correlation matrix (SPSS-X). A model-1 least squares regression (Sokal \& Rohlf 1981) was performed to examine the relationship between each dependent variable (Total-BSP, MacroBSP, Meio-BSP) and correlated variables. Analysis of covariance was employed to assess differences among slopes of all wind stress and production regressions.

The relationship of wind stress and the remaining environmental variables to benthic secondary production was examined through stepwise multiple regressions (SPSS-X) that selected the best predictors at $\alpha=$ 0.05 . Because the number of study sites where the headwind index could be calculated was limited, 2 multiple regressions were performed for each dependent $B S P$ variable. First, a regression was calculated using the entire data set (but excluding HW), and second, the regression was re-calculated using data only from those study sites where HW could be calculated.

\section{RESULTS}

\section{Data set}

A total of 201 published estimates of benthic secondary production were obtained without restrictions based on location of study site. Many diverse geographical areas were represented in the data set (e.g. New Zealand, Bermuda, southern India, Venezuela), however the prevalence of north temperate data sources (Canada and western Europe) should be noted (Appendix 1).

The maximum production of an entire benthic community in these data $\left(\sim 8000 \mathrm{~kJ} \mathrm{~m}^{-2} \mathrm{yr}^{-1}\right)$ was relatively similar to that of the Meio-BSP $\left(-6500 \mathrm{~kJ} \mathrm{~m}^{-2} \mathrm{yr}^{-1}\right.$; Table 1). Mean annual production of macrofauna and meiofauna were not significantly different $(\bar{x}=703$ and $800 \mathrm{~kJ} \mathrm{~m}^{-2} \mathrm{yr}^{-1}$ respectively; $p>0.05$ ). Mean annual pelagic and benthic primary production $(\sim 7000$ and $5000 \mathrm{~kJ} \mathrm{~m}^{-2} \mathrm{yr}^{-1}$, respectively) were greater than Total-BSP by a factor of 2 to 3 .

The contribution of the microbenthos to Total-BSP $(\sim 60 \%$; Fig. 1$)$ is consistent with recent suggestions that the bacterial contribution to Total-BSP should be lower than the $90 \%$ level traditionally assumed
Table 1. Descriptive statistics of biological and environmental variables in the data set. BSP: benthic secondary production; B/PPP: Benthic/Pelagic primary production $\left(\mathrm{kJ} \mathrm{m}^{-2} \mathrm{yI}^{-1}\right) ; \mathrm{CV}$ : coefficient of variation

\begin{tabular}{|lrrrrr|}
\hline Variable & Mean & CV (\%) & Min & Max & $N$ \\
\cline { 5 - 6 } Biotic & & & & & \\
Total-BSP & 2833 & $(81)$ & 197 & 7969 & 70 \\
Macro-BSP & 703 & $(101)$ & 16 & 3895 & 93 \\
Meio-BSP & 800 & $(157)$ & 2 & 6430 & 38 \\
BPP & 4492 & $(97)$ & 0 & 27187 & 89 \\
PPP & 7248 & $(119)$ & 200 & 43921 & 105 \\
Abiotic & & & & & \\
Temp. (C) & 11.8 & $(44.9)$ & 3 & 29 & 145 \\
Salinity (\%o) & 25.3 & $(28.1)$ & 6 & 37 & 143 \\
Depth (m) & 13.7 & $(200.7)$ & 0.5 & 200 & 145 \\
Tidal height (m) & 2.6 & $(126.9)$ & 0 & 14 & 145 \\
Sediment (0-5) & 3.0 & - & 2 & 5 & 145 \\
Headwind (deg.) & 86.1 & $(59.8)$ & 1 & 180 & 62 \\
Fetch (km) & 42.8 & $(161.0)$ & 0.05 & 323 & 145 \\
Wind stress (Pa) & 0.05 & $(38.0)$ & 0.01 & 0.08 & 144 \\
\hline
\end{tabular}

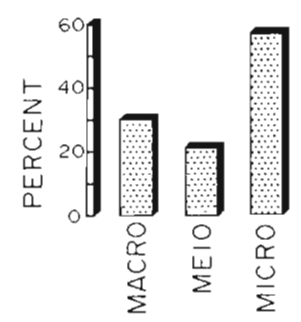

Fig. 1. Relative contributions of macro-, meio- and microbenthic secondary production to total benthic secondary production (obtained from the literature). Calculations were performed only from study sites where Total-BSP and one of the remaining size fractionated production estimates were known. Microbenthic production was calculated by difference

(Schwinghamer et al. 1986). Meiofaunal metabolism has been considered to be a small fraction of macrofaunal metabolism (e.g. Gerlach 1971), but it is not apparent in this data set; Macro- and Meio-BSP both represented $\sim 20$ to $30 \%$ of Total-BSP.

Low mean annual water temperature illustrates the prevalence of temperate study sites (Table 1). A number of estuarine sites resulted in a relatively low mean salinity $(25.3 \%$ ). Mean depth, tidal height and effective fetch had high coefficients of variation. The majority of benthic study sites were less than $20 \mathrm{~m}$ in depth. The range in mean annual wind stress was relatively narrow $(0.01$ to $0.08 \mathrm{~Pa})$.

\section{Wind stress and benthic production}

The correlation matrix (Table 2) shows that every component of primary and secondary production was significantly correlated with at least one of the wind 
Table 2. Pearson correlation matrix of biological production ( $\left.\mathrm{kJ} \mathrm{m}^{-2} \mathrm{yr}^{-1}\right)$ and environmental variables: Tot, Mac, and Mei are total-, macro-, and meio-benthic secondary production. BPP and PPP represent benthic and pelagic primary production

\begin{tabular}{|c|c|c|c|c|c|c|c|c|c|c|c|c|c|}
\hline & Tot & $M a c$ & Mei & BPP & PPP & $\mathrm{Te}$ & Z & Sal & $\mathrm{TH}$ & Sed & EF & HW & WS \\
\hline Total & 1 & $\begin{array}{l}0.54 \\
\ldots\end{array}$ & $\begin{array}{l}0.77 \\
\cdots\end{array}$ & $\begin{array}{l}0.65 \\
\cdots\end{array}$ & $\begin{array}{l}0.51 \\
\cdots\end{array}$ & $\begin{array}{l}0.39 \\
\cdots\end{array}$ & - & $\begin{array}{c}-0.22 \\
.\end{array}$ & -0.23 & - & $\begin{array}{c}-0.33 \\
. .\end{array}$ & $\begin{array}{l}0.45 \\
\cdots\end{array}$ & $\begin{array}{c}-0.56 \\
\cdots\end{array}$ \\
\hline Macro & & 1 & $\begin{array}{l}0.68 \\
\cdots\end{array}$ & - & - & - & - & - & - & - & -0.18 & - & $\begin{array}{c}-0.35 \\
\ldots\end{array}$ \\
\hline Meio & & & 1 & - & - & - & 0.35 & - & 0.28 & - & $\begin{array}{c}-0.51 \\
\cdots\end{array}$ & - & $\begin{array}{c}-0.72 \\
\cdots\end{array}$ \\
\hline BPP & & & & 1 & - & $\begin{array}{c}0.33 \\
\cdots\end{array}$ & $\begin{array}{c}-0.31 \\
\ldots\end{array}$ & - & - & - & $\begin{array}{c}-0.37 \\
\cdots\end{array}$ & 0.34 & - \\
\hline PPP & & & & & 1 & $\begin{array}{c}0.27 \\
\cdots\end{array}$ & - & - & - & - & - & $\begin{array}{l}0.54 \\
\cdots\end{array}$ & - \\
\hline Tempe & re $\left({ }^{\circ} \mathrm{C}\right)$ & & & & & 1 & $\begin{array}{c}-0.40 \\
\cdots\end{array}$ & $\begin{array}{c}0.21 \\
\cdots\end{array}$ & -0.18 & - & - & - & $\begin{array}{l}0.19 \\
\cdot\end{array}$ \\
\hline Depth & & & & & & & 1 & $\begin{array}{c}0.27 \\
\cdots\end{array}$ & - & - & - & - & - \\
\hline Salinity & & & & & & & & 1 & - & - & $\begin{array}{r}0.32 \\
\cdots\end{array}$ & - & - \\
\hline Tidal h & it $(\mathrm{m})$ & & & & & & & & 1 & - & - & $\begin{array}{c}-0.40 \\
\ldots\end{array}$ & $\begin{array}{c}-0.31 \\
\cdots\end{array}$ \\
\hline Sedime & ype 10 & & & & & & & & & 1 & - & - & - \\
\hline Effectiv & $\operatorname{tch}(\mathrm{k}$ & & & & & & & & & & 1 & -0.27 & - \\
\hline Headw & index & eg.) & & & & & & & & & & 1 & - \\
\hline Wind $s$ & $(\mathrm{~Pa})$ & & & & & & & & & & & & 1 \\
\hline \multicolumn{14}{|c|}{$\cdot p<0.05, \cdots p<0.01, \cdots p<0.001,-$ : not significant } \\
\hline
\end{tabular}

variables (wind stress, effective fetch, headwind index). In particular, wind stress and effective fetch were significantly correlated with all size components of benthic secondary production. These relationships indicate that as wind stress increases and shelter from the wind decreases, mean annual benthic production decreases.

Although there was considerable variance in the relationship between Macro-BSP and wind stress (Fig. 2b), wind stress accounted for 32 and $52 \%$ of the variance in Total-BSP and Meio-BSP respectively (Fig. $2 a, c)$. The intercepts of each regression equation were very similar $(b \approx 3)$, and analysis of covariance indicated that slopes for each regression were significantly different ( $p=0.028$ ).

The correlation matrix also revealed significant relations among water temperature, water depth, salinity, tidal height and various biological variables (Table 2 ). Sediment type was not correlated with any other variable.

\section{Multiple regression models}

Four of the 5 regression models incorporated wind stress as the most significant variable accounting for the observed variation in benthic secondary production
(Table 3). Only in the -Total-BSP model was wind stress subordinate; tidal height was the primary predictor variable. In the full Total-and Macro-BSP models, all predictor variables were directly wind-related $(\tau$, $E F, H W$ ) except for mean annual water temperature in the Total-BSP model, and water depth in the MacroBSP model.

The addition of the headwind index to the Total-BSP model increased the amount of variance which could be explained from 64 to $\sim 90 \%$. In addition, the high degree of scatter in the observed versus modelled plot of Macro-BSP was significantly reduced $\left(R^{2}=0.60\right.$ from 0.23 ) with the inclusion of the headwind index (Fig. 3 ; Table 3). The equation intercepts in all size group production models were equal to $\sim 4$.

All models included physical variables exclusively, although the correlation matrix (Table 2) indicated a significant relation existed between both benthic and pelagic primary production and total benthic secondary production. Meio-BSP and Macro-BSP were not significantly correlated with either BPP or PPP. Mean annual water temperature was included in the Total-BSP models, however, its contribution was relatively low. The established relation between bacterial concentration, POM and sediment surface area (Yamamoto \& Lopez 1985), was not apparent in the data, however the ab- 


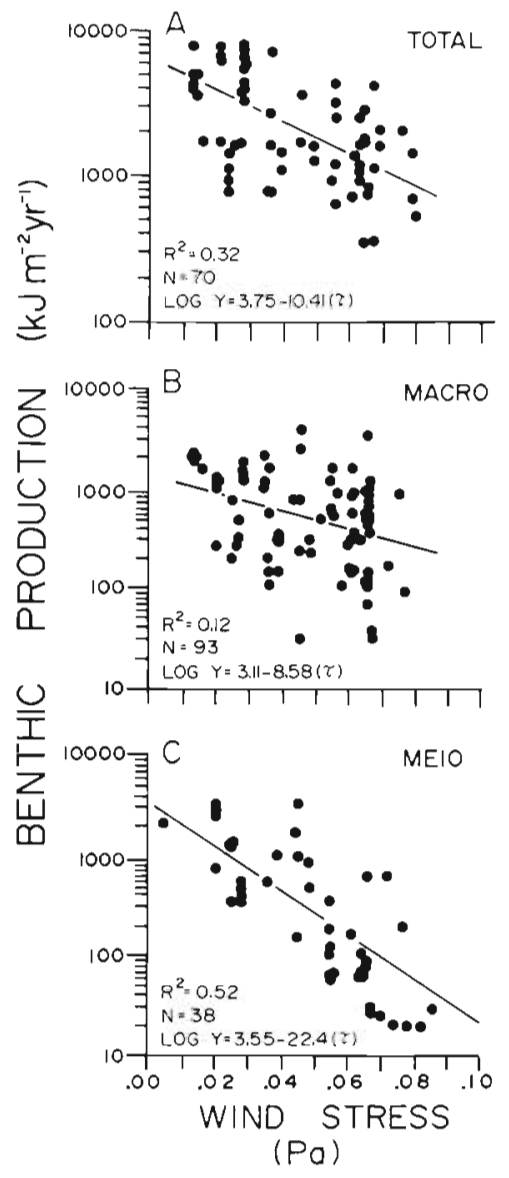

Fig. 2. Simple linear regressions of wind stress and (A) total-, (B) macro-, and (C) meio-benthic production. Coefficient of determination, number of data points and regression equation are listed sence of significant correlations of BSP (or BPP) with sediment type must be interpreted with regard to the very qualitative index and narrow range by which sediment type was described

\section{DISCUSSION}

Of 10 biological and physical variables considered, mean annual wind stress accounted for the most variation in 4 out of 5 models of benthic secondary production. This is consistent with the trophic group mutual exclusion hypothesis (Wildish 1977) which states that benthic productivity is food limited and that current acts as the exclusion mechanism; i.e. hydrodynamics control benthic energy flow.

It is apparent, from the significant negative correlations between wind stress and benthic secondary productivity, that the positive influence of wind forcing on production (e.g. increased organic seston flux: Frechette \& Bourget 1985, and a lowered redox potential discontinuity: Boynton et al. 1981, Rutgers van der Loeff 1981) is often subordinate to wind-related biological stress. Detrimental effects of wind-forced hydrodynamics on the benthic community can be partitioned into (1) those resulting from water movement below the critical shear velocity $(U \cdot c r i t)$ of the sediment, and (2) the effects of wind-forced currents which exceed U.crit.

Below $\mathrm{U}_{\text {crit, }}$ wind mixing can decrease the availability of primary production to the benthos by directly inhibiting photosynthesis and by increasing the residence time of particulate organic matter within the water column. The first effect has been summarized in

Table 3. Stepwise multiple regression models describing log-transformed Total-, Macro- and Meio-benthic secondary production $\left(\mathrm{kJ} \mathrm{m}{ }^{-2} \mathrm{yr}^{-1}\right)$. Models for those sites where the headwind index (HW) could be calculated. $\mathrm{\tau}$ : mean wind stress ( $\mathrm{Pa}$ ); TH: tidal height $(\mathrm{m})$, Te: mean water temperature $\left({ }^{\circ} \mathrm{C}\right) \mathrm{EF}$ : effective fetch $(\mathrm{km}), \mathrm{Z}$ : depth $(\mathrm{m}), \mathrm{lg}$ : log-transformed

\begin{tabular}{|c|c|c|c|c|}
\hline Step & Dependent variable & Model & $R^{2}$ & $F$ Signif \\
\hline 1. & Total & $=3.8-10.4(\tau)$ & 0.34 & 0.0000 \\
\hline 2. & $(N=70)$ & $=3.9-13.2(\tau)-0.3(\operatorname{lg~TH})$ & 0.47 & 0.0000 \\
\hline 3. & & $=3.6-11.7(\tau)-0.3(\lg \mathrm{TH})+0.02(\mathrm{Te})$ & 0.52 & 0.0000 \\
\hline 4. & & $=3.7-11.4(\tau)-0.3(\lg \mathrm{TH})+0.02(\mathrm{Te})-0.1(\mathrm{EF})$ & 0.64 & 0.0000 \\
\hline 1. & $\cdot$ Total & $=3.4-0.4(\lg \mathrm{TH})$ & 0.36 & 0.0014 \\
\hline 2. & $(N=39)$ & $=3.9-0.4(\lg \mathrm{TH})-13.0(\tau)$ & 0.64 & 0.0000 \\
\hline 3. & & $=3.9-0.2(\lg \mathrm{TH})-18.4(\tau)-0.1(\lg \mathrm{EF} / \mathrm{HW})$ & 0.83 & 0.0000 \\
\hline 4. & & $=3.7-0.2(\mathrm{lg} \mathrm{TH})-16.9(\tau)-0.1(\mathrm{lg} \mathrm{EF} / \mathrm{HW})+0.02(\mathrm{Te})$ & 0.87 & 0.0000 \\
\hline 1. & Macro & $=3.1-8.6(\tau)$ & 0.12 & 0.0006 \\
\hline 2. & $(N=93)$ & $=3.2-9.7(\tau)-0.1(\lg Z)$ & 0.23 & 0.0000 \\
\hline 1. & - Macro & $=3.4-18.2(\tau)$ & 0.28 & 0.0007 \\
\hline \multirow[t]{2}{*}{2.} & $(N=37)$ & $=4.2-16.8(\tau)-0.4(\lg E F / H W)$ & 0.41 & 0.0001 \\
\hline & & $=4.5-16.8(\tau)-0.5(\lg \mathrm{EF} / \mathrm{HW})-0.2(\lg \mathrm{Z})$ & 0.60 & 0.0000 \\
\hline 1. & Meio & $=3.5-22.4(\tau)$ & 0.52 & 0.0000 \\
\hline 2. & $(N=38)$ & $=3.5-19.7(\tau)-0.2(\lg Z)$ & 0.63 & 0.0000 \\
\hline
\end{tabular}




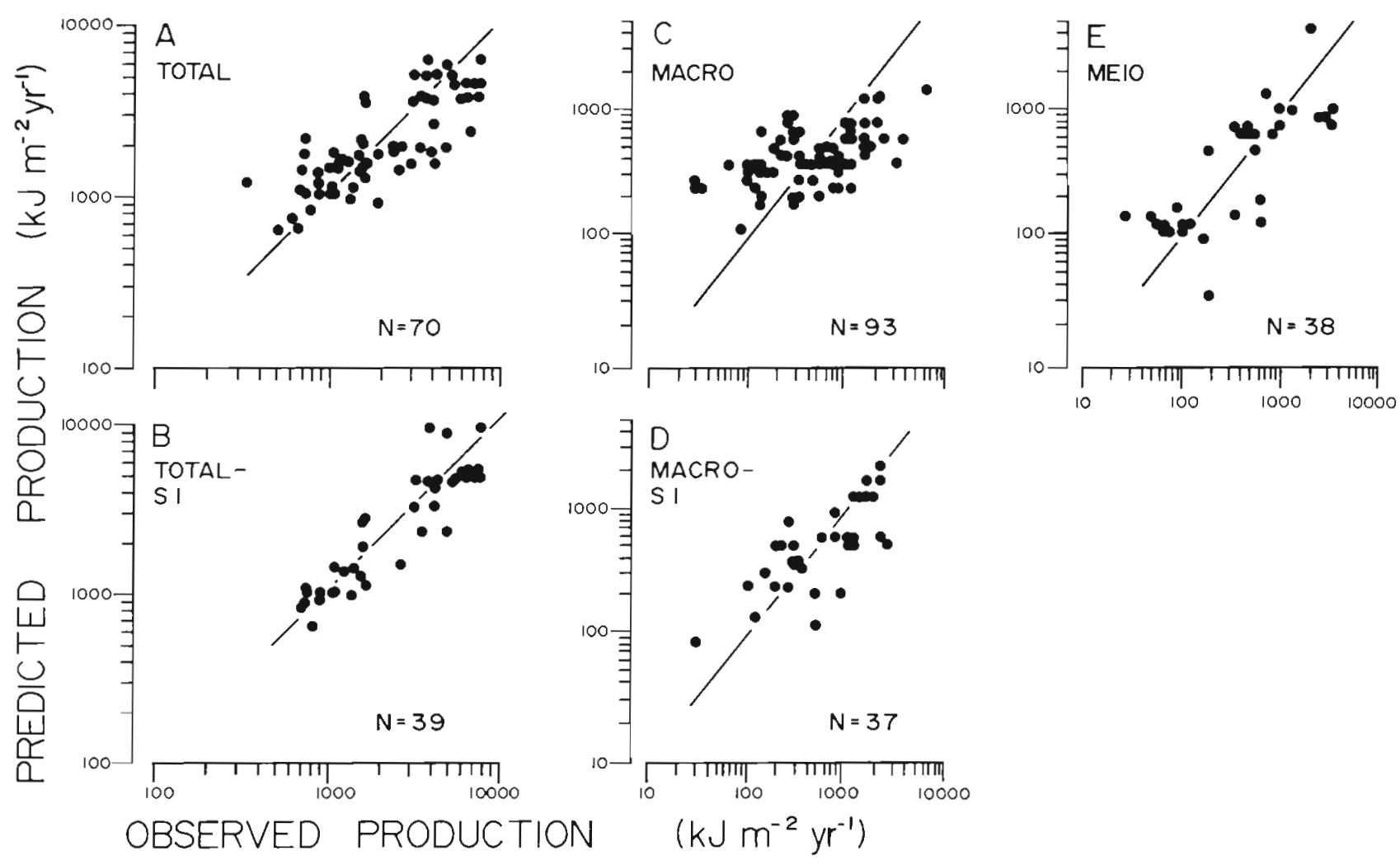

Fig. 3. Observed (A) total-, (C) macro-, and (E) meio-benthic production plotted against predicted production derived from regression analyses. Plotted line represents a 1:1 relationship. (B) Total-and (D) macro-production plots include only those data from sites for which headwind index could be calculated. SI: shelter index

Sverdrup's critical depth model of phytoplankton photosynthesis (Parsons et al. 1984). Simply stated, if the critical depth (the depth at which photosynthesis equals respiration) is less than the depth of mixing, no net primary production can take place. It is reasonable to assume, therefore, that annual primary production would be lower in areas where high winds frequently mix the phytoplankton below the critical depth. Secondly, the increase in retention time of photosynthetically-derived POM within the water column will favour the consumption of POM by planktonic heterotrophs.

The former effect is not likely to be significant because the shallow mean depth represented in the data set $(14 \mathrm{~m})$ minimizes possible light limitation resulting from plankton downwelling. The significance of the latter effect will be minimal because the food supply to shallow benthic communities is not solely dependent on the passive sinking of POM. Intertidal suspension feeders have been shown to rapidly filter a large proportion of the water column, thus effectively competing with the plankton for available seston (Nichols 1985, Smaal et al. 1986, Emerson et al. 1988). Alternative mechanisms which would contribute to lower community productivity at high wind stress (visà-vis increased water turbulence) include direct inhibi- tion of suspension feeding (Wildish \& Kristmanson 1979. Wildish \& Peer 1983) and a decreased likelihood of larval settlement (Rhoads \& Young 1970). It is likely, however, that the dominant negative effects of wind forcing on shallow, coastal communities occur when $\mathrm{U}$. crit is exceeded.

The cumulative effect of the many biologicallyimportant processes associated with sediment transport are manifest in the productivity of the benthos. When $\mathrm{U} \cdot$ crit is exceeded, the erosion and transport of fine, organic-rich particles initially will subsidize a foodlimited community (De Jonge \& Van den Bergs 1987. Grant et al. 1987). However, prolonged erosion, or an increased shear velocity (U.), will raise the proportion of non-nutritive inorganic particles in the seston, lower primary production via shading from an increased suspended particulate load, and deplete POM in the sediment. This scenario is analogous to the 'reverse ramp function' described for scallop growth (Wildish et al. 1987); after initial increases in growth with current speed, growth inhibition was observed with flows of $>10$ to $20 \mathrm{~cm} \mathrm{~s}^{-1}$. The postulated mechanism of scallop growth inhibition involved a reduction in food ration due to a reduction in filtration rate.

The importance of sediment movement to benthic 
energetics has been highlighted in the scaling arguments of Miller et al. (1984). They contend that food availability to epibenthic deposit feeders can be determined primarily from the examination of sediment transport rate and particle residence time, along with several biological factors. Organism removal (Thistle 1988) and direct mortality resulting from abrasion and burial (Yeo \& Risk 1979, Maurer et al. 1986) are some of the more catastrophic phenomena associated with increased bedload at higher current speeds.

The requisite conditions for bulk sediment transport at the study sites subject to high wind stress are present if it is assumed that as the water depth approaches zero (e.g. on intertidal flats) the bottom shear stress can be approximated by the estimated surface wind stress. If $\tau=0.07 \mathrm{~Pa}$ (in the higher range of the wind-stress data set), U. $=23.2$ $\mathrm{cm} \mathrm{s}^{-1}$, which is well above $(20 \times)$ the $\mathrm{U} \cdot$ crit of natural sediment $\left(\mathrm{U} \cdot \mathrm{cnt}=0.66\right.$ to $1.38 \mathrm{~cm} \mathrm{~s}^{-1}$; Grant \& Bathmann 1987). The probable overestimate of $U$. resulting from the above assumptions is balanced by underestimates inherent in the wind stress formula (Eq. 2 ; see Thompson et al. 1983) and by additional interactive tidal and residual shear stresses imposed on the sea bed (Pattiaratchi \& Collins 1985). Furthermore, my approximation of $U$. is consistent with observations of significant POM resuspension at depths greater than $6 \mathrm{~m}$ caused by winds less

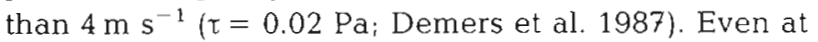
depths greater than $100 \mathrm{~m}$, winter storms can generate a U. 10 times larger than U. crit, and can transport $\sim 1000 \mathrm{~kg}$ $\mathrm{m}^{-2} \mathrm{~d}^{-1}$ of resuspended sediment across the continental shelf (Drake \& Cacchione 1985).

The relationships between wind stress and the 3 size classes of BSP in the data set are consistent with the effects of burial, abrasion, and organism removal associated with wind-forced bedload transport. In regressions of wind stress and BSP, the highest correlation and steepest slope was observed for meiobenthic secondary production. Total-BSP, $80 \%$ of which is accounted for by micro- and meiofaunal production (Fig. 1), was also highly correlated with wind stress. Because these smaller organisms $(<1 \mathrm{~mm})$ inhabit the sediment interstices or live directly on grain surfaces, they are particularly vulnerable to the effects of sediment transport (Palmer \& Molloy 1986, Fegley 1987). Macrofauna are less susceptible because of their relative size, mobility or ability to burrow (Grant 1981). Removal of food supply, inhibition of feeding, injury from abrasion and direct mortality will translate a high susceptibility to sediment transport into a lower annual secondary production. If the wind stress-production correlations were a consequence of bedload transport, the coefficient of determination should increase as the size of organism responsible for production decreases. Results from both multiple and simple regression analyses have clearly reflected these patterns.
Although these regression results cannot be uniquely attributed to the effects of sediment transport, the differential expression of other wind-forced effects are more likely to be observed between mode of feeding (deposit vs. suspension feeders) than between size of organism. A wind-related decrease in primary production would induce acute restrictions in food supply to suspension feeders, yet only affect deposit feeders (regardless of size) over a longer term.

\section{Benthic production models}

My empirical approach to describing benthic energetics has identified the dominant role of physical variables; ca $90 \%$ of the variation in total benthic secondary production can be explained by wind stress, effective fetch, headwind index, tidal height, and mean annual water temperature. Benthic and pelagic primary production were not selected as predictor variables in any benthic production model. The results are particularly intriguing in view of previous studies which have emphasized the dominant role of primary production in benthic energy flow. It should be re-emphasized however, that the lack of spatial and temporal correlations between sites of published primary production data and those of benthic secondary production may be responsible for the absence of primary production from the multiple regression models. Although the results of the regression analyses do not exclude the possibility that low benthic production at high wind stress was a consequence of a decrease in photosynthetically-derived food (from light limitation due to increased turbidity; Hargrave et al. 1983), the absence of $B / P P P$ in the models substantiates the hypothesis of Wildish \& Kristmanson (1979) that an impoverished community is limited by effects of hydrodynamic forcing (e.g. sediment instability or a direct feeding inhibition) and not by a food supply limitation.

The relatively high $Q_{10}$ of bacteria and other microfauna should imply that water temperature contributes significantly to the variance in Total-BSP. Indeed, this is reflected in the results (Table 3 ), however the inclusion of annual mean water temperature resulted in only a minimal improvement to the model $(\sim 5 \%)$. Previous studies have indicated that changes in water temperature alone accounted for $>50 \%$ of the short-term variation in benthic metabolism (Hargrave 1969, Grant 1986). These discrepancies may be resolved through the refinement of data collection; better spatial and temporal matches between BSP estimates and environmental variables, and an emphasis on variance rather than on mean values (e.g. frequency of storms) will improve the models. 
Appendix 1. Sources of data used in regression analysis $(X)$ of benthic production and environmental variables. Depth $(Z, m)$, number of stations, secondary production (meio-, macro-, and total-benthic), and primary production (benthic and pelagic) are listed. ' Intertidal tidal height $(\mathrm{m})$

\begin{tabular}{|c|c|c|c|c|c|c|c|c|c|}
\hline Location & & Z & $\begin{array}{l}\text { No. } \\
\text { stns }\end{array}$ & Mei & $\mathrm{Mac}$ & Tot & $\mathrm{BPP}$ & $\mathrm{PPP}$ & Source \\
\hline Australia & $34^{\circ} 04^{\prime} \mathrm{S}, 151^{\circ} 09^{\prime} \mathrm{E}$ & 5 & 1 & - & $\mathrm{X}$ & - & - & $\mathrm{x}$ & Rainer (1982) \\
\hline Belgium & $51^{\circ} 15^{\prime} \mathrm{N}, 03^{\circ} 00^{\prime} \mathrm{E}$ & 55 & 6 & $x$ & - & - & - & - & Heip et al. (1984) \\
\hline Bermuda & $32^{\circ} 30^{\prime} \mathrm{N}, 64^{\circ} 40^{\prime} \mathrm{W}$ & 2 & 2 & $\mathrm{x}$ & $\mathrm{x}$ & $\mathrm{x}$ & - & $x$ & Smith et al. (1972) \\
\hline \multirow[t]{13}{*}{ Britain } & $57^{\circ} 20^{\prime} \mathrm{N}, 02^{\circ} 00^{\prime} \mathrm{W}$ & $3^{\cdot}$ & 1 & $x$ & $\mathrm{x}$ & - & $\mathrm{X}$ & $\mathrm{x}$ & Baird \& Milne (1981) \\
\hline & $57^{\circ} 20^{\prime} \mathrm{N}, 02^{\circ} 00^{\prime} \mathrm{W}$ & $3^{*}$ & 1 & - & $\mathrm{x}$ & - & $\mathrm{X}$ & - & Leach (1970), Chambers \& Milne (1975) \\
\hline & $57^{\circ} 48^{\prime} \mathrm{N}, 02^{\circ} 00^{\prime} \mathrm{W}$ & 25 & 1 & - & - & $\mathrm{x}$ & - & $\mathrm{x}$ & Steel \& Baird 1968, Davies (1975) \\
\hline & $57^{\circ} 48^{\prime} \mathrm{N}, 05^{\circ} 36^{\prime} \mathrm{W}$ & $5^{*}$ & 1 & - & $x$ & $\mathrm{x}$ & $\mathrm{x}$ & $\mathrm{x}$ & Mc Intyre \& Eleftherion (1968), Van Es (1982) \\
\hline & $55^{\circ} 10^{\prime} \mathrm{N}, 01^{\circ} 25^{\prime} \mathrm{W}$ & 58 & 1 & - & $\mathrm{X}$ & - & - & - & Buchanan \& Warwick (1974) \\
\hline & $55^{\circ} 00^{\prime} \mathrm{N}, 03^{\circ} 00^{\prime} \mathrm{E}$ & 50 & 1 & $\mathrm{X}$ & $x$ & - & $x$ & $x$ & Jones (1984) \\
\hline & $50^{\circ} 50^{\prime} \mathrm{N}, 01^{\circ} 10^{\prime} \mathrm{W}$ & $3^{\bullet}$ & 1 & - & $\mathrm{x}$ & - & - & - & Hibbert (1976) \\
\hline & $35^{\circ} 15^{\prime} \mathrm{N}, 04^{\circ} 03^{\prime} \mathrm{W}$ & 8 & 1 & - & $x$ & - & - & - & Hughes (1970) \\
\hline & $50^{\circ} 14^{\prime} \mathrm{N}, 04^{\circ} 16^{\prime} \mathrm{W}$ & $2^{\circ}$ & 1 & - & $x$ & - & $\mathrm{x}$ & $x$ & Joint (1978) \\
\hline & $50^{\circ} 24^{\prime} \mathrm{N}, 04^{\circ} 16^{\prime} \mathrm{W}$ & $2^{*}$ & 1 & $\mathrm{x}$ & $x$ & $\mathrm{x}$ & $\mathrm{x}$ & - & $\begin{array}{l}\text { Warwick \& Price (1975), Warwick et al. (1979), } \\
\text { Colijn \& de Jonge (1984) }\end{array}$ \\
\hline & $51^{\circ} 30^{\prime} \mathrm{N}, 00^{\circ} 45^{\prime} \mathrm{E}$ & $2^{\circ}$ & 1 & - & $x$ & - & - & - & Mossmann (1978) \\
\hline & $51^{\circ} 40^{\prime} \mathrm{N}, 04^{\circ} 28^{\prime} \mathrm{W}$ & 14 & 1 & - & $x$ & - & - & - & Warwick et al. (1978) \\
\hline & $50^{\circ} 27^{\prime} \mathrm{N}_{1} 04^{\circ} 13^{\prime} \mathrm{W}$ & $3^{\cdot}$ & 1 & $\mathrm{x}$ & $\mathrm{x}$ & $\mathrm{x}$ & $\mathrm{x}$ & - & Ellison $(1984)$ \\
\hline \multirow[t]{27}{*}{ Canada } & $44^{\circ} 37^{\prime} \mathrm{N}, 63^{\circ} 30^{\prime} \mathrm{W}$ & 60 & 1 & - & - & $\mathrm{x}$ & - & $x$ & Hargrave $(1980)$ \\
\hline & $54^{\circ} 31^{\prime} \mathrm{N}, 05^{\circ} 33^{\prime} \mathrm{W}$ & $1^{\bullet}$ & 1 & $\mathrm{x}$ & $\mathrm{X}$ & $\mathrm{x}$ & $\mathrm{X}$ & - & Boaden \& Elhag (1984) \\
\hline & $45^{\circ} 44^{\prime} \mathrm{N}, 64^{\circ} 29^{\prime} \mathrm{W}$ & $12^{\cdot}$ & 1 & $\mathrm{X}$ & $\mathrm{X}$ & $\mathrm{x}$ & $\mathrm{X}$ & $\mathrm{X}$ & Prouse et al. (1984), Schwinghamer et al. (1986) \\
\hline & $45^{\circ} 44^{\prime} \mathrm{N}, 64^{\circ} 29^{\prime} \mathrm{W}$ & $12^{\cdot}$ & 1 & - & - & $\mathrm{x}$ & $\mathrm{x}$ & $\mathrm{x}$ & Hargrave et al. (1983) \\
\hline & $45^{\circ} 44^{\prime} \mathrm{N}, 64^{\circ} 29^{\prime} \mathrm{W}$ & $12^{\bullet}$ & 1 & - & $\mathrm{x}$ & - & $\mathrm{X}$ & $\mathrm{X}$ & Colijn \& de Jonge (1984), Cranford et al. (1985) \\
\hline & $45^{\circ} 44^{\prime} \mathrm{N}, 64^{\circ} 29^{\prime} \mathrm{W}$ & $12^{\cdot}$ & 2 & - & $\mathrm{x}$ & - & $\mathrm{x}$ & $\mathrm{X}$ & Hawkins (1985) \\
\hline & $45^{\circ} 44^{\prime} \mathrm{N}, 64^{\circ} 29^{\prime} \mathrm{W}$ & $12^{\circ}$ & 1 & - & $\mathrm{X}$ & - & - & - & Peer (1984) \\
\hline & $45^{\circ} 49^{\prime} \mathrm{N}, 64^{\circ} 20^{\prime} \mathrm{W}$ & $14^{*}$ & 1 & - & $\mathrm{X}$ & - & $\mathrm{X}$ & - & Cranford et al. (1985) \\
\hline & $45^{\circ} 46^{\prime} \mathrm{N}, 64^{\circ} 40^{\prime} \mathrm{W}$ & $14^{\circ}$ & 1 & - & $\mathrm{X}$ & - & $\mathrm{X}$ & - & Cranford et al. (1985) \\
\hline & $45^{\circ} 47^{\prime} \mathrm{N}, 64^{\circ} 32^{\prime} \mathrm{W}$ & $14^{\cdot}$ & 1 & - & $\mathrm{x}$ & - & $x$ & - & Cranford et al. (1985) \\
\hline & $45^{\circ} 45^{\prime} \mathrm{N}, 64^{\circ} 37^{\prime} \mathrm{W}$ & $14^{*}$ & 1 & - & $\mathrm{X}$ & - & $X$ & - & Cranford et al. (1985) \\
\hline & $45^{\circ} 20^{\prime} \mathrm{N}, 64^{\circ} 37^{\prime} \mathrm{W}$ & $12^{*}$ & 7 & - & - & $\mathrm{x}$ & $\mathrm{X}$ & $\mathrm{x}$ & Hargrave et al. (1983) \\
\hline & $45^{\circ} 50^{\prime} \mathrm{N}, 64^{\circ} 20^{\prime} \mathrm{W}$ & $12^{\bullet}$ & 1 & - & $\mathrm{X}$ & - & $x$ & $\mathrm{X}$ & Peer (1984), Prouse et al. (1984) \\
\hline & $45^{\circ} 45^{\prime} \mathrm{N}, 64^{\circ} 37^{\prime} \mathrm{W}$ & $11^{\circ}$ & 1 & - & $\mathrm{X}$ & - & $\mathrm{x}$ & $\mathrm{x}$ & Peer (1984), Prouse et al. (1984) \\
\hline & $45^{\circ} 20^{\prime} \mathrm{N}, 64^{\circ} 10^{\prime} \mathrm{W}$ & $10^{\circ}$ & 3 & - & $\mathrm{x}$ & - & $\mathrm{x}$ & $\mathrm{X}$ & Peer (1984), Prouse et al. (1984) \\
\hline & $45^{\circ} 10^{\prime} \mathrm{N}, 64^{\circ} 15^{\prime} \mathrm{W}$ & $12^{\cdot}$ & 2 & - & $\mathrm{x}$ & - & $\mathrm{x}$ & $\mathrm{X}$ & Peer (1984), Prouse et al. (1984) \\
\hline & $45^{\circ} 00^{\prime} \mathrm{N}, 66^{\circ} 00^{\prime} \mathrm{W}$ & 100 & 1 & - & $\mathrm{X}$ & - & - & $\mathrm{X}$ & Wildish \& Peer (1983), Emerson et al. (1986) \\
\hline & $44^{\circ} 45^{\prime} \mathrm{N}, 56^{\circ} 10^{\prime} \mathrm{W}$ & $2 \cdot$ & 1 & - & $\mathrm{X}$ & - & - & $\mathrm{x}$ & Burke \& Mann (1974) \\
\hline & $44^{\circ} 37^{\prime} \mathrm{N}, 63^{\circ} 30^{\prime} \mathrm{W}$ & $2^{*}$ & 1 & - & $\mathrm{X}$ & $\mathrm{x}$ & $\mathrm{x}$ & - & Hargrave \& Phillips (1981), Grant (1986) \\
\hline & $44^{\circ} 37^{\prime} \mathrm{N}, 66^{\circ} 30^{\prime} \mathrm{W}$ & $2^{\bullet}$ & 1 & - & - & $\mathrm{x}$ & $\mathrm{X}$ & - & Van Raalte (1978) \\
\hline & $49^{\circ} 09^{\prime} \mathrm{N}, 123^{\circ} 54^{\prime} \mathrm{W}$ & $6^{\circ}$ & 1 & $\mathrm{X}$ & - & $\mathrm{x}$ & $\mathrm{x}$ & - & Naimann \& Silbert (1979) \\
\hline & $44^{\circ} 15^{\prime} \mathrm{N}, 63^{\circ} 00^{\prime} \mathrm{W}$ & 60 & 1 & - & $\mathrm{X}$ & - & - & $\mathrm{X}$ & Mills \& Fournier (1979) \\
\hline & $42^{\circ} 15^{\prime} \mathrm{N}, 68^{\circ} 00^{\prime} \mathrm{W}$ & 50 & 1 & $\mathrm{x}$ & $\mathrm{X}$ & - & $\mathrm{X}$ & $\mathrm{X}$ & Sissenwine et al. (1984) \\
\hline & $44^{\circ} 25^{\prime} \mathrm{N}, 64^{\circ} 00^{\prime} \mathrm{W}$ & 60 & 1 & - & $\mathrm{X}$ & - & - & $x$ & Platt (1971), MacKinnon (1973) \\
\hline & $44^{\circ} 35^{\prime} \mathrm{N}, 64^{\circ} 00^{\prime} \mathrm{W}$ & 60 & 1 & - & $x$ & - & - & $\mathrm{X}$ & Hargrave \& Phillips (1986) \\
\hline & $44^{\circ} 25^{\prime} \mathrm{N}, 64^{\circ} 00^{\prime} \mathrm{W}$ & 60 & 1 & - & - & $\mathrm{x}$ & - & $\mathrm{x}$ & Hargrave (1973) \\
\hline & $45^{\circ} 43^{\prime} \mathrm{N}, 61^{\circ} 32^{\prime} \mathrm{W}$ & 30 & 1 & - & $\mathrm{x}$ & - & - & $\mathrm{x}$ & Hargrave \& Phillips (1986) \\
\hline \multirow[t]{6}{*}{ Denmark } & $55^{\circ} 03^{\prime} \mathrm{N}, 08^{\circ} 25^{\prime} \mathrm{E}$ & $1^{*}$ & 3 & - & $x$ & $\mathrm{x}$ & $x$ & $\mathrm{x}$ & Asmus $(1982 a, b)$, Reise $(1985)$ \\
\hline & $55^{\circ} 43^{\prime} \mathrm{N}, 11^{\circ} 43^{\prime} \mathrm{E}$ & 0.5 & 3 & - & $\mathrm{X}$ & - & $\mathrm{X}$ & $\mathrm{x}$ & Birklund (1977), Colijn \& de Jonge (1984) \\
\hline & $55^{\circ} 58^{\prime} \mathrm{N}, 12^{\circ} 41^{\prime} \mathrm{E}$ & 28 & 1 & - & $\mathrm{X}$ & $\mathrm{x}$ & $\mathrm{x}$ & $x$ & Gargas (1970), Kanneworff \& Christensen (1986) \\
\hline & $56^{\circ} 55^{\prime} \mathrm{N}, 09^{\circ} 10^{\prime} \mathrm{E}$ & 8 & 1 & - & - & $x$ & $\mathrm{x}$ & - & Van Es (1982) \\
\hline & $55^{\circ} 03^{\prime} \mathrm{N}, 08^{\circ} 25^{\prime} \mathrm{E}$ & $2^{*}$ & 2 & - & $\mathrm{x}$ & $\mathrm{x}$ & $\mathrm{x}$ & $\mathrm{X}$ & Asmus \& Asmus (1985) \\
\hline & $56^{\circ} 20^{\prime} \mathrm{N}, 12^{\circ} 50^{\prime} \mathrm{E}$ & 20 & 5 & - & - & $\mathrm{x}$ & $\mathrm{x}$ & - & Graneli \& Sundback (1986) \\
\hline \multirow{7}{*}{$\begin{array}{l}\text { Finland } \\
\text { F.R. } \\
\text { Germany }\end{array}$} & $59^{\circ} 50^{\prime} \mathrm{N}, 23^{\circ} 12^{\prime} \mathrm{E}$ & 46 & 1 & - & $\mathrm{x}$ & - & - & $\mathrm{x}$ & Kuparinen et al. (1984) \\
\hline & $54^{\circ} 40^{\prime} \mathrm{N}, 10^{\circ} 00^{\prime} \mathrm{E}$ & 22 & 1 & $\mathrm{x}$ & $\mathrm{x}$ & - & - & $\mathrm{x}$ & Nichols (1977a) \\
\hline & $54^{\circ} 40^{\prime} \mathrm{N}, 10^{\circ} 00^{\prime} \mathrm{E}$ & 1 & 1 & - & - & $\mathrm{x}$ & - & $x$ & Van Es (1982) \\
\hline & $54^{\circ} 40^{\prime} \mathrm{N}, 10^{\circ} 00^{\prime} \mathrm{E}$ & $1 \hat{1}$ & 1 & $\mathrm{X}$ & $x$ & $x$ & - & $\mathrm{X}$ & Van Es (1982) \\
\hline & $54^{\circ} 40^{\prime} \mathrm{N}, 10^{\circ} 00^{\prime} \mathrm{E}$ & 15 & 1 & $\mathrm{X}$ & $\mathrm{X}$ & $\mathrm{x}$ & - & $x$ & Arntz \& Brunswig (1975), Von Brockel (1975) \\
\hline & $54^{\circ} 40^{\prime} \mathrm{N}, 10^{\circ} 00^{\prime} \mathrm{E}$ & 20 & 1 & $\mathrm{x}$ & - & $\mathrm{x}$ & - & $\mathrm{x}$ & Arntz \& Brunswig (1976), Von Brockel (1975) \\
\hline & $54^{\circ} 01^{\prime} \mathrm{N}, 07^{\circ} 49^{\prime} \mathrm{E}$ & 34 & 1 & $\mathrm{x}$ & $\mathrm{X}$ & $\mathrm{x}$ & - & - & Gerlach et al. (1985) \\
\hline
\end{tabular}


Appendix 1 (continued)

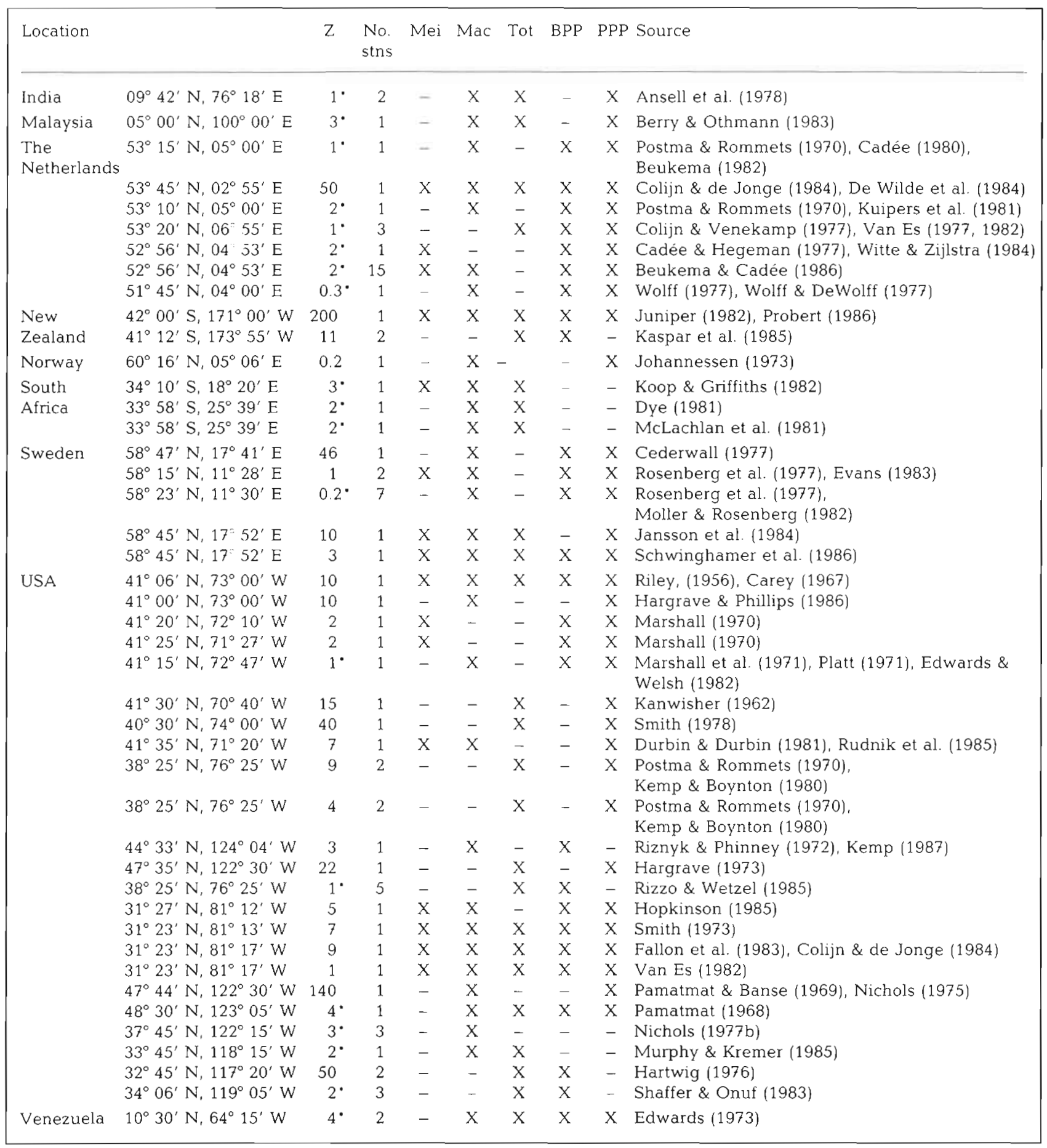

In summary, the empirical models presented in this study have suggested that wind, tidal and temperature data (all easily and routinely measured) can be employed to predict the annual secondary production of the benthos in coastal, soft-bottom communities. At present, the exact mechanism linking these environmental variables to benthic production is uncertain, however it is hoped that with the identification of these dominant variables, elucidation of the mechanisms regulating benthic production will be facilitated. In addition, the results show that investigations of vertical energy exchange must consider horizontal fluxes of particulate matter in order to clearly define pelagicbenthic energy coupling. 
Acknowledgements. Assistance and encouragement from K. R. Thompson and C. T. Marshall were greatly appreciated Comments and suggestions by J. Grant, B. T Hargrave, E. L. Mills, C. T Taggart and 3 anonymous reviewers greatly improved an earlier version of the manuscript. Financial support was obtained from the Natural Sciences and Engineering Council of Canada through an operating grant to B.T.H. and E.L.M.

\section{LITERATURE CITED}

Ansell, A. D., McLusky, D. S., Stirling, A., Trevallion, A (1978). Production and energy flow in the macrobenthos of two sandy beaches in South West India. Proc. R. Soc. Edinb. 76 (B): 269-296

Arntz, W. E., Brunswig, D. (1975). An approach to estimating the production of macrobenthos and demersal fish in the western Baltic Abra alba community. Merentutkimuslait. Julk. Havsforskinst. Skr. 239: 195-205

Arntz, W. E., Brunswig, D. (1976). Studies on structure and dynamics of macrobenthos in the western Baltic carried out by the joint research program 'Interaction sea-sea bottom'. In: Persoone, G., Jaspers, E. (ed.) Proc. 10th European Mar. Biol. Symp. Vol. 2. Universa Press, Wetteren, p. $17-42$

Asmus, H. (1982a). Field measurements on respiration and secondary production of a benthic community in the northern Wadden Sea. Neth. J. Sea Res. 16: 403-413

Asmus, R. (1982b). Field measurements on seasonal variation of the activity of primary producers on a sandy tidal flat in the northern Wadden Sea. Neth. J. Sea Res. 16: 389-402

Asmus, H., Asmus, R. (1985). The importance of grazing food chain for energy flow and production in three intertidal sand bottom communities of the northern Wadden Sea. Helgoländer Meeresunters. 39 (3): 273-301

Baird, D., Milne, H. (1981). Energy flow in the Ythan Estuary, Aberdeenshire. Scotland. Estuar. coast. Shelf Sci. 13: $455-472$

Berry, A. J., Othman, Z. B. (1983). An annual cycle of recruitment, growth and production in a Malaysian population of the Trochacean gastropod Umbonium rectiarium (L.). Estuar coast. Shelf Sci. 17: 357-363

Beukema, J. J. (1982). The role of the larger invertebrates in the Wadden Sea ecosystem. In: Wolff, W J. (ed.) Ecology of the Wadden Sea. Balkema, Rotterdam, p. 211-221

Beukema, J. J., Cadée, G. C. (1986). Zoobenthos responses to eutrophication of the Dutch Wadden Sea. Ophelia 26: 55-64

Birklund, J. (1977). Biomass, growth and production of the amphipod Corophium insidiosum Crawford, and preliminary notes on Corophium volutator (Pallas). Ophelia 16 (2): $187-203$

Boaden, J. G., Elhag, E. A. G. (1984). Meiobenthos and the oxygen budget of an intertidal sand beach. Hydrobiologia 118: $39-47$

Boynton, W. R., Kemp, W. M., Osborne, C. G., Kaumeyer, K. R., Jenkins, M. C. (1981). Influence of water circulation rate on in situ measurements of benthic community respiration. Mar Biol. 65: 185-190

British Meteorology Office (1952). Climatological atlas of the British Isles. H. M. Stationery Office, London

Buchanan, J. B., Warwick, R. M. (1974). An estimate of benthic macrofaunal production in the offshore mud of the Northumberland Coast. J. mar biol. Ass. U.K. 54: 197-222

Burke, M. V., Mann, K. H. (1974). Productivity and produc- tion: biomass ratios of bivalve and gastropod populations in an eastern Canadian estuary. J. Fish. Res. Bd Can. 31: $167-177$

Cadée, G. C., Hegeman, J. (1977). Distribution of primary production of the benthic microflora and accumulation of organic matter on a tidal flat area, Balgzand, Dutch Wadden Sea. Neth. J. Sea Res. 11. 24-41

Cadée, G. C. (1980). Reappraisal of the production and import of organic carbon in the western Wadden Sea. Neth. J. Sea Res. 14: 305-322

Carey, A. G. Jr (1967). Energetics of the benthos of Long Island Sound. I. Oxygen utilization of sediment. Bull. Bingham oceanogr. Coll. 19: 136-144

Cederwall, H. (1977). Annual macrofauna production of a soft bottom in the northern Baltic proper. In: Keegan, B. F., O'Ceidigh, P., Boaden, P. J. S. (eds.) Proc. 11 th Europ. Mar. Biol. Symp. Pergamon Press, Oxford, p. 155-172

Chambers, M. R., Milne, H. (1975). Life cycle and production of Nereis diversicolor O. F. Muller in the Ythan Estuary, Scotland. Estuar. coast. mar. Sci. 3: 133-144

Colijn, F., Venekamp, L. (1977). Benthic primary production in the Ems-Dollard estuary during 1975. Hydrobiol. Bull. 11: $16-17$

Colijn, F., de Jonge, $V$ N. (1984). Primary production of microphytobenthos in the Ems-Dollard Estuary. Mar. Ecol. Prog. Ser 14: 185-196

Cranford, P. J., Peer, D. L., Gordon, D. C. (1985). Population dynamics and production of Macoma balthica in Cumberland Basin and Shepody Bay, Bay of Fundy. Neth. J. Sea Res. $19(2)$ : 135-146

Crisp, D. J. (1971). Energy flow measurements. In: Holme, N. A., McIntyre, A. D. (eds.) Methods for the study of marine benthos. Blackwell Sci. Publ., Oxford, p. 197-280

Davies, J. M. (1975). Energy flow through the benthos in a Scottish Sea loch. Mar. Biol. 31. 353-362

Demers, S., Therriault, J.-C., Bourget, E., Bah, A. (1987). Resuspension in the shallow sublittoral zone of a macrotidal estuarine environment: wind influence. Limnol. Oceanogr. 32 (2): $327-339$

De Jonge, V. N., van den Bergs, J. (1987). Experiments on the resuspension of estuarine sediments containing benthic diatoms. Estuar. coast. Shelf Sci. 24: 725-740

De Wilde, P. A. W. J., Beukema, J. J. (1984). The role of the zoobenthos in the consumption of organic matter in the Dutch Wadden Sea. Neth. J. Sea Res. Publ. Ser. 10-1984: 145-158

Drake, D. E., Cacchione, D. A. (1985). Seasonal variations in sediment transport on the Russian River shelf, California. Cont. Shelf Res. 4: 495-514

Durbin, A. G., Durbin, E. G. (1981). Standing stock and estimated production rates of phytoplankton and zooplankton in Narragensett Bay, Rhode Island. Estuaries 4: 24-41

Dye, A. H. (1981). A study of benthic oxygen consumption on exposed sandy beaches. Estuar. coast. Shelf Sci. 13: 671-680

Edwards, R. R. C. (1973). Production ecology of two Caribbean marine systems. Il. Metabolism and energy flow. Estuar. coast mar. Sci. 1: 319-333

Edwards, S. F., Welsh, B. L. (1982). Trophic dynamics of a mudsnail [Ilyanassa obsoleta (Say)] population of an intertidal mudflat. Estuar. coast. Shelf Sci. 14: 663-686

Ellison, R. L. (1984). Foraminifera and meiofauna on an intertidal mudflat, Cornwall, England: populations; respiration and secondary production; and energy budget. Hydrobiologia 109: 131-148

Emerson, C. W., Roff, J. C., Wildish, D. J. (1986). Pelagicbenthic energy coupling at the mouth of the Bay of Fundy Ophelia 26: 165-180 
Emerson, C. W., Minchinton, T. E., Grant, J. (1988). Population structure, biomass and respiration of the soft-shell clam Mya arenaria L. on a temperate sandflat. J. exp. mar. Biol. Ecol. 115: 99-111

Evans, S. (1983). Production, predation and food niche segregation in a marine shallow soft-bottom community. Mar Ecol. Prog. Ser 10: 147-157

Fallon, R. D., Newell, S. Y., Hopkinson, C. S. (1983). Bacterial production in marine sediments: will cell-specific measures agree with whole-system metabolism? Mar. Ecol. Prog. Ser $11 \quad 119-127$

Fegley, S. R. (1987). Experimental variation of near-bottom current speeds and its effects on depth distribution of sand-living meiofauna. Mar. Biol. 95: 183-191

Findlay, R. H., Pollard, P. C., Moriarty, D. J. W., White, D. C. (1985). Quantitative determination of microbial activity and community nutritional status in estuarine sediments: evidence for a disturbance artifact. Can. J. Microbiol. 31: $493-498$

Frechette, M., Bourget, E. (1985). Energy flow between the pelagic and benthic zones: factors controlling particulate organic matter available to an intertidal mussel bed. Can. J. Fish. Aquat. Sci. 42 (6): 1158-1165

Gargas, E. (1970). Measurements of primary production, dark fixation and vertical distribution of the microbenthic algae in the Oresund. Ophelia 8: 231-253

Gerlach, S. A. (1971). Life cycles in marine meiobenthos. Experiments at various temperatures with Monhystera disjuncta and Theristus pertenuis (Nematoda). Mar. Biol. $9(3): 274-280$

Gerlach, S. A., Hahn, A. E., Schrage, M. (1985). Size spectra of benthic biomass and metabolism. Mar. Ecol. Prog. Ser. 26 $161-173$

Gordon, D. C. Jr, Keizer, P. D., Schwinghamer, P., Daborn, G R. (1987). Ecological evaluation of the Cumberland Basin ecosystem model. Cont. Shelf Res. 7 (11/12): 1477-1482

Graf, G., Bengtsson, W., Fanbel, A., Meyer-Reil, L.-A., Schulz, R., Theede, H., Thiel, H. (1984). The importance of spring phytoplankton bloom for the benthic system of the Kiel Bight. Rapp. P.-v. Réun. Cons. int. Explor. Mer. 183: 136-143

Graneli, W. Sundback, K. (1986). Can microbenthic photosynthesis influence below-halocline oxygen conditions in the Kattegat? Ophelia 26: 195-206

Grant, J. (1981). Sediment transport and disturbance on an intertidal sandflat: infaunal distribution and recolonization. Mar. Ecol. Prog. Ser. 6: 249-255

Grant, J. (1986). Sensitivity of benthic community respiration and primary production to changes in temperature and light. Mar Biol. 90: 291-306

Grant, J., Bathmann, U. V (1987). Swept away: resuspension of bacterial mats regulates benthic-pelagic exchange of sulfur. Science 236: 1472-1474

Grant, J., Volckaert, F., Roberts-Regan, D. L. (1987). Resuspendable organic matter in Nova Scotian shelf and slope sediments. Cont. Shelf Res. 7 (9): 1123-1138

Hargrave, B. T. (1969). Similarity of oxygen uptake by benthic communities. Limnol. Oceanogr. 14 (5): 801-805

Hargrave, B. T. (1973). Coupling carbon flow through some pelagic and benthic communities. J. Fish. Res. Bd Can. 30: $1317-1326$

Hargrave, B. T. (1980). Factors affecting the flux of organic matter to sediments in a marine bay. In: Tenore, $K$. R., Coull, B. C. (eds.) Marine benthic dynamics. University of South Carolina Press, Columbia, p. 243-263

Hargrave, B. T., Phillips, G. A. (1981). Annual in situ carbon dioxide and oxygen flux across a subtidal marine sediment. Estuar. coast. Shelf Sci. 12: 725-737
Hargrave, B. T., Phillips, G. A. (1986). Dynamics of the benthic food web in St. Georges Bay, southern Gulf of St. Lawrence. Mar. Ecol. Prog. Ser 31 (3): 277-294

Hargrave, B. T., Prouse, N. J., Phillips, G. A., Neame, P. A (1983). Primary production and respiration in pelagic and benthic communities at two intertidal sites in the upper Bay of Fundy. Can. J. Fish. Aquat. Sci. 40 (Suppl. 1): 229-243

Hartwig, E. O. (1976). Nutrient cycling between the water column and a marine sediment. I. Organic carbon. Mar Biol. 34: 285-295

Hartwig, E. O. (1978). Factors affecting respiration and photosynthesis by the benthic community of a subtidal silicious sediment. Mar. Biol. 46: 283-293

Hawkins, C. M. (1985). Population carbon budgets and the importance of the amphipod Corophium volutator in the carbon transfer on a Cumberland Basin mudflat, upper Bay of Fundy, Canada. Neth. J. Sea Res. 19: 165-176

Heip, C., Herman, R., Vinex, M. (1984). Variability and productivity of meiobenthos in the southern bight of the North Sea. Rapp. P.-v. Réun. Cons. int. Explor. Mer 183: 51-56

Hibbert, C. J. (1976). Biomass and production of a bivalve community on an intertidal mud-flat. J. exp. mar Biol. Ecol. 25: 249-261

Hinga, K. R., Sieburth, J. M., Heath, G. R. (1979). The supply and use of organic material at the deep-sea floor. J. mar. Res. 37 (3): 557-579

Holme, N. A., McIntyre, A. D. (eds.) (1971). Methods for the study of marine benthos. Blackwell Sci. Publ., Oxford

Hopkinson, C. S. Jr (1985). Shallow-water benthic and pelagic metabolism: evidence of heterotrophy in the nearshore Georgia Bight. Mar Biol. 87: 19-32

Hughes, R. N. (1970). An energy budget for a tidal-flat population of the bivalve Scrobicularia plana (Da Costa). J. Anim. Ecol. 39: 357-379

Jansson, B.-O., Wilmot, W., Wulff, F. (1984). Coupling the subsystems - the Baltic Sea as a case study. In: Fasham, M. J. R. (ed.) Flows of energy and materials in marine ecosystems. Theory and practice. Plenum Press, New York, p. 549-595

Johannessen, O. H. (1973). Length and weight relationships and the potential production of the bivalve Venerupis pullastra (Montagu) on a sheltered beach in western Norway. Sarsia 53: 41-48

Joint, I. R. (1978). Microbial production of an estuarine mudflat. Estuar. coast. mar. Sci. 7: 185-195

Jones, R. (1984). Some observations on energy transfer through the North Sea and Georges Bank food webs. Rapp. P.-v. Réun. Cons. int. Explor. Mer 183: 204-217

Jumars, P. A., Self, R. F. L. (1986). Gut-marker and gutfullness methods for estimating field and laboratory effects of sediment transport on ingestion rates of deposit feeders. J. exp. mar. Biol. Ecol 98: 293--310

Juniper, S. K. (1982). Regulation of microbial production in intertidal mudflats - the role of Amphibola crenata, a deposit feeding gastropod. Ph. D. thesis, University of Canterbury, Christchurch, New Zealand

Kanneworff, E., Christensen, H. (1986). Benthic community respiration in relation to sedimentation of phytoplankton in the Oresund. Ophelia 26: 269-284

Kanwisher, J. (1962). Gas exchange of shallow marine sediments. Occ. Publ. Grad. Sch. Oceanogr., Univ. Rhode Island, 4: 191-204

Kaspar, H. F., Gillespie, P. A., Boyer, I. C., MacKenzie, A. L. (1985). Effects of mussel aquaculture on the nitrogen cycle and the benthic communities in Kenepuru Sound, Marlborough Sounds, New Zealand. Mar. Biol. 85: 127-136 
Kemp, P. F. (1987). Potential impact on bacteria of grazing by a macrofaunal deposit-feeder, and the fate of bacterial production. Mar Ecol. Prog. Ser 36 (2): 151-161

Kemp, W. M., Boynton, W. R. (1980). Influence of biological and physical processes on dissolved oxygen dynamics in an estuarine system: implications for measurement of community metabolism. Estuar. coast. Shelf Sci. 11: 407-431

Koop, K., Griffiths, C. L. (1982). The relative significance of bacteria, meio- and macrofauna on an exposed sandy beach. Mar. Biol. 66: 295-300

Kuipers, B. R., De Wilde, P. A. W. J., Creutzberg, F. (1981) Energy flow in a tidal flat ecosystem. Mar. Ecol. Prog. Ser. 5: $215-221$

Kuparinen, J., Leppanen, J.-M., Sarvala, J., Sundberg, A. Virtanen, A. (1984). Production and utilization of organic matter in a Baltic ecosystem off Tvarminne, southwest coast of Finland. Rapp. P.-v. Réun. Cons. int. Explor. Mer 183: $180-192$

Leach, J. H. (1970). Epibenthic algal production in an intertidal mudflat. Limnol. Oceanogr. 15 (4): 514-520

Lesht, M., Hawley, N. (1987). Near-bottom currents and suspended sediment concentration in southeastern Lake Michigan. J. Grt. L. Res. 13 (3): 375-383

Levasseur, M., Therriault, J. C., Legendre, L. (1983). Tidal currents, wind and the morphology of phytoplankton spatial structures. J. mar. Res, 42: 655-672

Lewis, M. R., Horne, E. P. W., Cullen, J. J., Oakey, N. S., Platt, T. (1984). Turbulent motions may control phytoplankton photosynthesis in the upper ocean. Nature, Lond. 311 $49-50$

Mackinnon, J. C. (1973). Analysis of energy flow and production in an unexploited marine flatfish population. J. Fish. Res. Bd Can. 30:1717-1728

Marshall, N. (1970). Food transfer through the lower trophic levels of the benthic environment. In: Steele, J. H. (ed.) Marine food chains. University of California Press, Berkeley, p. 52-66

Marshall, N., Oviatt, C. A., Skanen, D. M. (1971). Productivity of the benthic microflora of shoal estuarine environments in southern New England. Int. Rev. ges. Hydrobiol. 56 (6): 947-956

Maurer, D., Keck, R. T., Tinsman, J. C., Leathem, W. A. Wethe, C., Lord, C., Church, T. M. (1986). Vertical migration and mortality of marine benthos in dredged material: a synthesis. Int. Revue ges. Hydrobiol. 71. 49-63

McIntyre, A. D., Eleftherion, A. (1968). The bottom fauna of a flatfish nursery ground. J. mar. biol. Ass. U.K. 48: 113-142

McLachlan, A., Erasmus, T., Dye, A. H., Wooldridge, T., Van der Horst, G., Rossouw, G., Lasiak, T. A., McGwynne, L. (1981). Sand beach energetics: an ecosystem approach towards a high energy interface. Estuar. coast. Shelf Sci. 13: 11-25

Miller, D. C., Jumars, P. A. (1986). Pellet accumulation, sediment supply and crowding as determinants of surface deposit-feeding rate in Pseudopolydora kempi japonica Imajima and Hartman (Polychaeta: Spionidae). J. exp. mar. Biol. Ecol. 99: 1-18

Miller, D. C., Jumars, P. A., Nowell, A. R. M. (1984). Effects of sediment transport on deposit feeding: scaling arguments. Limnol. Oceanogr. 29 (6): 1202-1217

Mills, E. L., Fournier, R. O. (1979). Fish production and the marine ecosystems of the Scotian Shelf, eastern Canada. Mar. Biol. 54: 101-108

Moller, P., Rosenberg, R. (1982). Production and abundance of the amphipod Corophium volutator on the west coast of Sweden. Neth. J. Sea Res. 16: 127-140

Mossmann, D. E. (1978). The energetics of Corophium volutator. Ph. D. thesis, University of London
Murphy, R. C., Kremer, J. N. (1985). Bivalve contribution to benthic metabolism in a California lagoon. Estuaries 8 (4): $330-341$

Naiman, R. J., Sibert, J. R. (1979). Detritus and juvenile salmon production in the Nanaimo estuary: III Importance of detrital carbon to the estuarine ecosystem. Can. J. Fish. Aquat. Sci. 36: 504-520

Nichols, F. H. (1975). Dynamics and energetics of three deposit-feeding benthic invertebrate populations in Puget Sound, Washington. Ecol. Monogr. 45: 57-82

Nichols, F. H. (1977a). Dynamics and production of Pectinaria koreni (Malmgren) in Kiel Bay, West Germany. In: Keegna, B. F., O'Ceidigh, P., Boaden, P. J. S. (eds.) Proc. 11 th Eur. Symp. Mar. Biol. Pergamon Press, Oxford, p. 453-463

Nichols, F. H. (1977b). Infaunal biomass and production on a mudflat, San Francisco, Bay, California. In: Coull, B. C. (ed.) Ecology of marine benthos. University of South Carolina Press, Columbia, p. 339-358

Nichols, F. H. (1985). Increased benthic grazing: an alternative explanation for low phytoplankton biomass in northern San Francisco Bay during the 1976-1977 drought. Estuar. coast. Shelf Sci. 21: 379-388

Palmer, M. A., Molloy, R. M. (1986). Water flow and the vertical distribution of meiofauna: a flume experiment. Estuaries 9 (3): $225-228$

Pamatmat, M. M. (1968). Ecology and metabolism of a benthic community on an intertidal sandflat. Int. Revue ges. Hydrobiol. 53 (2): 211-298

Pamatmat, M. M., Banse, K. (1969). Oxygen consumption by the seabed. II. In situ measurements to a depth of $180 \mathrm{~m}$. Limnol. Oceanogr. 14: 250-259

Parsons, T R., Takahashi, M., Hargrave, B. (1984). Biological oceanographic processes. Pergamon Press, Oxford

Pattiaratchi, C. B., Collins, M. B. (1985). Sand transport under the combined influence of waves and tidal currents: an assessment of available formulae. Mar. Geol. 67: 83-100

Peer, D. L. (1984). A review of benthic macrofaunal production of the upper Bay of Fundy intertidal area. In: Gordon, D. C. Jr, Dadswell, M. J. (eds.) Update on the marine environmental consequences of tidal power development in the upper reaches of the Bay of Fundy. Can. Tech. Rep. Fish. Aquat. Sci. No. 1256, p. 105-114

Pejrup, M. (1986). Parameters affecting fine-grained suspended sediment concentrations in a shallow micro-tidal estuary, Ho Bugt, Denmark. Estuar. coast. Shelf Sci. 22: 241-254

Pingree, R. D. (1980). Mixing and stabilization of phytoplankton distributions on the northwest European continental shelf. In: Steele, J. H. (ed.) Spatial pattern in plankton communities. Plenum Press, New York, p. $181-220$

Platt, T. (1971). The annual production by phytoplankton in St Margaret's Bay, Nova Scotia. J. Cons. int. Explor. Mer $33(3): 324-333$

Postma, H., Rommets, J. W. (1970). Primary production in the Wadden Sea. Neth. J. Sea Res. 4 (4): 470-493

Probert, P. K. (1986). Energy transfer through the shelf benthos off the west coast of South Island. New Zealand. N.Z. Jl mar Freshwat. Res. 20: 407-417

Prouse, N. J., Gordon, D. C. Jr, Hargrave, B. T., Bird, C J. McLachlan, J., Lakshminarayana, J. S. S., Sita Devi, J., Thomas, M. L. H. (1984). Primary production: organic matter supply to ecosystems in the Bay of Fundy. In: Gordon, D. C. Jr, Dadswell, M. J. (eds.) Update on the marine environmental consequences of tidal power development in the upper reaches of the Bay of Fundy. Can. Tech. Rep. Fish. Aquat. Sci. No. 1256, p. 65-96 
Rainer, S. F. (1982). Trophic structure and production in the macrobenthos of a temperate Australian estuary. Estuar coast Shelf Sci. 15: 423-441

Reise, K. (1985). Tidal flat ecology. Springer-Verlag, Berlin

Rhoads, D. C. Young, D. K. (1970). The influence of depositfeeding organisms on sediment stability and community trophic structure. J. mar. Res. 28: 150-178

Riley, G. A. (1956). Oceanography of Long Island Sound, 1952-1954. IX. Production and utilization of organic matter Bull. Bingham oceanogr Coll. 15: 324-344

Riznyk, R. Z., Phinney, H. K. (1972). Manometric assessment of interstitial microalgae production in two estuarine sediments. Oecologia (Berl.) 10: 193-203

Rizzo, W. M., Wetzel, R. L. (1985). Intertidal and shoal benthic community metabolism in a temperate estuary: studies of spatial and temporal scales of variability. Estuaries $8(4)$ : 342-351

Rosenberg, R., Olsson, I, Olundh, E. (1977). Energy flow model of an oxygen-deficient estuary on the Swedish west coast. Mar. Biol. 42: 99-107

Rowe, G. T. (1971). Benthic biomass and surface productivity. In: Costlow, D. Jr (ed.) Fertility of the sea. Gordon and Breach, New York, p. 441-454

Rudnick, D. T., Elmgren, R., Frithsen, J. B. (1985). Meiofaunal prominence and benthic seasonality in a coastal marine ecosystem. Oecologia (Berl.) 67: 157-168

Ruffner, J. A. (1978). Climates of the States. Vol. 1-2. Gale Res. Co., Book Tower, Detroit

Rutgers van der Loeff, M. M. (1981). Wave effects on sediment water exchange in a submerged sand bed. Neth. J. Sea Res. 15 (1): 100-112

Schwinghamer, P., Hargrave, B. T., Peer, D., Hawkins, C. M. (1986). Partitioning of production and respiration among size groups of organisms in an intertidal benthic community. Mar Ecol Prog. Ser 31: 131-142

Shaffer, G. P. Onuf, C. P. (1983). An analysis of factors influencing the primary production of the benthic microflora in a southern California lagoon. Neth. J. Sea Res. 17 (1): 126-144

Sissenwine, M. P., Cohen, E. B., Grosslein, M. D. (1984). Structure of the Georges Bank ecosystem. Rapp. P.-v. Réun. Cons. int. Explor. Mer 183: 243-254

Smaal, A. C., Verhagen, J. H. G., Coosen, J., Haas, H. A. (1986). Interaction between seston quantity and quality and benthic suspension feeders in the Oosterschelde. The Netherlands. Ophelia 26: 365-400

Smith, K. L. Jr (1973). Respiration of a sublittoral community. Ecology 54: 1065-1075

Smith, K. L. Jr (1978). Benthic community respiration in the northwest Atlantic ocean: in situ measurements from 40-5200 m. Mar. Biol. 47: 337-347

Smith, K. L. Jr, Burns, K. A., Teal, J. M. (1972). In situ respiration of benthic communities in Castle Harbor, Bermuda. Mar. Biol. 12: 196-199

Sokal, R. R., Rohlf, F. J. (1981). Biometry. W. H. Freeman and Co., New York

Soniat, T. M., Ray, S. M., Jeffrey, L. M. (1984). Components of the seston and possible available food for oysters in Galveston Bay, Texas. Contr. mar. Sci. 27: 127-141
Steele, J. H., Baird, J. (1968). Production ecology of a sandy beach. Limnol. Oceanogr 13 (1): 14-25

Thistle, D. (1988). A temporal difference in harpacticoidcopepod abundance at a deep-sea site: caused by benthic storms? Deep Sea Res. 35 (6): 1015-1020

Thompson, K. R., Marsden, R. F., Wright, D. G. (1983). Estimation of low-frequency wind stress fluctuations over the open ocean. J. phys. Oceanogr 13 (6): 1003-1011

U.S. Navy (1974). Marine climatic atlas of the world, Vol.1, North Atlantic Ocean. Navair 50-1C-528, Washington D.C.

Van Es, F. B. (1977). A preliminary carbon budget for a part of the Ems estuary The Dollard. Helgolander wiss. Meeresunters. 30: 283-294

Van Es, F. B. (1982). Community metabolism of intertidal flats in the Ems-Dollard-Estuary. Mar. Biol. 66: 95-108

Van Raalte, C. (1978). The application of the ATP bioluminescent assay in the study of marine sediments. M. Sc. thesis, Dalhousie University, Halifax

Von Brockel, K. (1975). Der Energiefluß im pelagischen Ökosystem vor Boknis Eck (westl. Ostsee). Dissertation Univ, Kiel

Warwick, R. M., George, C. L., Davies, J. R. (1978). Annual macrofauna production in a Venus community. Estuar. coast. mar. Sci. 7: 215-241

Warwick, R. M., Joint, I. R., Radford, P. J. (1979). Ecological processes in coastal environments. Blackwell Sci. Publ., Oxford

Warwick, R. M. Price, R. (1975). Macrofauna production in an estuarine mud-flat. J. mar biol. Ass. U.K. 55: 1-18

Wildish, D. J. (1977). Factors controlling marine and estuarine sublittoral macrofauna. Helgoländer wiss. Meeresunters. 30: 445-454

Wildish, D. J., Kristmanson, D. D. (1979). Tidal energy and sublittoral macrobenthic animals in estuaries. J. Fish. Res. Bd Can. 36: 1197-1206

Wildish, D. J., Kristmanson, D. D. Hoar, R. L., DeCoste, A. M., McCormick, S. D., White, A. W. (1987). Giant scallop feeding and growth responses to flow. J. exp. mar. Biol. Ecol. 113: 207-220

Wildish, D. J, Peer, D. (1983). Tidal current speed and production of benthic macrofauna in the lower Bay of Fundy. Can J. Fish. Aquat. Sci. 40 (Suppl. 1): 309-321

Witte, J. I. J., Zijlstra, J. J. (1984). The meiofauna of a tidal flat in the western part of the Wadden Sea and its role in the benthic ecosystem. Mar. Ecol. Prog. Ser 14: 129-138

Wolff, W. J. (1977). A benthic food budget for the Grevelingen estuary, The Netherlands, and a consideration of the mechanisms causing high benthic secondary production in estuaries. In: Coull, B. C. (ed.) Ecology of marine benthos. University of South Carolina Press, Columbia, p. 267-280

Wolff, W. J., de Wolff, L. (1977). Biomass and production of zoobenthos in the Grevelingen Estuary, The Netherlands Estuar. coast. mar. Sci. 5: 1-24

Yamamoto, N., Lopez, G. (1985). Bacterial abundance in relation to surface area and organic content of marine sediments. J. exp. mar. Biol. Ecol. 90: 209-220

Yeo, R., Risk, M. J. (1979). Intertidal catastrophes: effects of storms and hurricanes on intertidal benthos of the Minas Basin, Bay of Fundy. Can. J. Fish. Aquat. Sci. 36: 667-669

Manuscript first received: May 3, 1988

Revised version accepted: January 25, 1989 